\title{
Luteibacter rhizovicinus gen. nov., sp. nov., a yellow-pigmented gammaproteobacterium isolated from the rhizosphere of barley (Hordeum vulgare L.)
}

\author{
Correspondence \\ Lars Mølbak \\ lam@dfvf.dk
}

\author{
Jens E. Johansen, ${ }^{1}$ Svend J. Binnerup, ${ }^{1}$ Niels $\mathrm{Kroer}^{1}$ and Lars Mølbak ${ }^{2}$ \\ 'Department of Environmental Chemistry and Microbiology, National Environmental Research \\ Institute, Frederiksborgvej 399, DK-4000 Roskilde, Denmark \\ 2Department of Bacteriology, Danish Veterinary Institute, Bülowsvej 27, DK-1790 København V, \\ Denmark
}

Soil adjacent to plant roots (the rhizosphere) usually supports a larger number and diversity of culturable bacteria than bulk soil (Lilley et al., 1996; Marilley \& Aragno, 1999; Johansen \& Binnerup, 2002) probably due to release of exudates and sloughed off cells from the root tissue. The

Published online ahead of print on 1 July 2005 as DOI 10.1099/ ijs.0.63497-0.

Abbreviations: ERIC, enterobacterial repetitive intergenic consensus sequence; RAPD, random amplified polymorphic DNA.

The GenBank/EMBL/DDBJ accession numbers for the 16S rRNA gene sequences of the strains LJ79, LJ96 ${ }^{\top}$ and LJ99 are AJ580497AJ580499, respectively.

Fatty acid profiles of $\mathrm{LJ}^{\top} 6^{\top}$ and Fulvimonas soli DSM $14263^{\top}$ and ERIC-PCR and RAPD fingerprints of $\mathrm{LJ}^{\mathrm{T}}{ }^{\top}$ and related species are available as supplementary material in IJSEM Online. culturable rhizosphere bacteria obtained on standard laboratory substrates are usually dominated by copiotrophic bacteria, such as Bacillus species (Germida et al., 1998), Cytophaga-like bacteria (Johansen \& Binnerup, 2002), Enterobacter species (Mahaffee \& Kloepper, 1997), Pseudomonas species and Xanthomonas species (Lilley et al., 1996).

Members of the family Xanthomonadaceae (Gammaproteobacteria) are known to have diverse metabolic potential (Finkmann et al., 2000; Mergaert et al., 2002; Nalin et al., 1999) and can be isolated from habitats like plants roots, contaminated soil and humans (Drancourt et al., 1997; Hauben et al., 1999; Swings et al., 1980; Wells et al., 1987). In recent years, several new genera have been included in the family Xanthomonadaceae. In the present paper, we suggest another genus of the family by providing a phylogenetic and phenotypic characterization of three 
yellow-pigmented strains. The strains represent a novel species within a novel genus, Luteibacter rhizovicinus gen. nov., sp. nov.

The isolates originated from rhizosphere soil of a spring barley (Hordeum vulgare L.) plant grown on an organic field at Højbakkegaard (Taastrup, Denmark). See Johansen \& Binnerup (2002) for further details concerning the isolation procedure. The strains appeared on $1 / 10$ TSBA $[3.0 \mathrm{~g}$ tryptic soy broth $\mathrm{l}^{-1}$ solidified with $15 \cdot 0 \mathrm{~g}$ agar $\mathrm{l}^{-1}$ (Difco), $\mathrm{pH} 7 \cdot 0]$ after 6 days of incubation at $15^{\circ} \mathrm{C}$ in darkness. Single colonies were subcultured to ensure purity. The strains were preserved at $-80{ }^{\circ} \mathrm{C}$ in a suspension of sterile MilliQ water and $15 \%$ glycerol. Rhodanobacter lindaniclasticus LMG $18385^{\mathrm{T}}$ originating from soil enriched with lindane (Nalin et al., 1999), Frateuria aurantia DSM $6220^{\mathrm{T}}$ isolated from the plant Lilium auratum Lindl (Swings et al., 1980) and Fulvimonas soli DSM $14263^{\mathrm{T}}$ originating from soil enriched with acetylated starch plastic (Mergaert et al., 2002) were also included in the study. Since Rhodanobacter lindaniclasticus $\mathrm{LMG} 18385^{\mathrm{T}}$ is no longer available from the BCCM/LMG, other public strain collections or from the authors (D. Janssens, Curator at BCCM/LMG Bacteria Collection, personal communication), only the genus and species description and the 16S rRNA gene sequence (GenBank accession no. AF039167) were used. Each of the three genera Rhodanobacter, Frateuria and Fulvimonas contains only a single species. Frateuria aurantia DSM $6220^{\mathrm{T}}$ and Fulvimonas soli DSM $14263^{\mathrm{T}}$ were cultured according to the recommendations of the Deutsche Sammlung von Mikroorganismen und Zellkulturen (DSMZ).

Transmission electron microscopy of $\mathrm{LJ} 96^{\mathrm{T}}$ was done using the whole mount preparation technique. Approximately $10 \mu \mathrm{l}$ of a culture of $\mathrm{LJ} 96^{\mathrm{T}}$, grown to exponential phase, was placed on a Formvar and carbon-coated grid and allowed to dry for about $30 \mathrm{~min}$. Cells were killed by $2 \%(\mathrm{v} / \mathrm{v})$ osmium tetroxide solution vapour for $30 \mathrm{~s}$. The grid was dried completely, washed in distilled water for $10 \mathrm{~min}$ and placed on a drop of $2 \%(\mathrm{v} / \mathrm{v})$ uranyl acetate for $5 \mathrm{~min}$ in darkness. Cells were examined in a JEOL electron microscope JEM-1010. Lysis with $3 \% \mathrm{KOH}$ was used to determine whether isolates were Gram-positive or -negative (Buck, 1982). Catalase activity was detected by the presence of bubbles after the addition of one drop of $3 \% \mathrm{H}_{2} \mathrm{O}_{2}$ to colonies growing on 1/10 TSBA plates. Cytochrome oxidase activity was considered positive when cells formed blue pigments after being streaked on filter paper wetted with $1 \% \quad N, N, N^{\prime}, N^{\prime}$-tetramethyl-p-phenyldiamine dihydrochloride (Merck). Change of colony colour (yellow to weak orange) was tested by adding $10 \%(\mathrm{w} / \mathrm{v}) \mathrm{KOH}$ to a 2day-old colony grown on 1/10 TSBA. Hydrolytic enzyme activity of $\alpha$-amylase, $\alpha$-cellulase, $\beta$-mannanase, $\beta$-xylanase was tested by adding $0.5 \mathrm{~g}$ chromogenic azurine-crosslinked (AZCL) substrates $1^{-1}$ (MegaZyme) to $1 / 10$ TSBA plates. Starch degradation was tested by adding $5.0 \mathrm{~g}$ starch $1^{-1}$ (Merck) to 1/10 TSBA plates. Clearing zones on starchamended 1/10 TSBA plates were detected after dripping
Lugol solution (Fluka) on the surface of the plates. Protease activity was tested by addition of sterilized skimmed milk (Difco) $\left(50 \cdot 0 \mathrm{~g} \mathrm{l}^{-1}\right)$ to $1 / 10$ TSBA plates. The plates were incubated for up to 6 days at $20^{\circ} \mathrm{C}$ and analysed daily for colour reactions (AZCL substrates) or clearing zones (skimmed milk and starch) around colonies. The ability to grow on 1/10 TSBA under anaerobic conditions was tested with the Oxoid Anaerobic system and agar plates were incubated for 3 days at $20^{\circ} \mathrm{C}$. The commercial systems API 20NE and API 50CHE (bioMérieux) were performed as recommended by the manufacturer using overnight cultures grown on 1/10 TSBA plates. All API tests were read after 3 days of incubation at $20^{\circ} \mathrm{C}$. Growth at different $\mathrm{pH}$ was studied on $1 / 10$ TSBA plates by adjusting the $\mathrm{pH}$ with $\mathrm{HCl}$ or $\mathrm{NaOH}$ to $\mathrm{pH} 6,7,8$ and 9. The salt tolerance was tested on $1 / 10$ TSBA plates containing $0,0 \cdot 5,1,2 \cdot 0,3 \cdot 0$ and $5.0 \%(\mathrm{w} / \mathrm{v}) \mathrm{NaCl}$. To test growth at different temperatures, $5 \mu \mathrm{l}$ overnight cultures were placed on 1/10 TSBA plates and incubated at $5,10,15,20,30$ and $37^{\circ} \mathrm{C}$ for up to 25 days. The fatty acid methyl ester profile of strain $2 J 96^{\mathrm{T}}$ was prepared by culturing at $20^{\circ} \mathrm{C}$ for 3 days in $1 / 10$ TSB and then identified by the DSMZ using standard methods (Sasser, 1990).

DNA was extracted by suspending a small amount of a colony in $200 \mu \mathrm{l}$ Tris/EDTA buffer $(1 \mathrm{M}$ Tris/ $\mathrm{HCl}, 0.5 \mathrm{M}$ EDTA, pH 7.5) and boiling at $102{ }^{\circ} \mathrm{C}$ for $10 \mathrm{~min}$. Cell debris was removed by centrifugation at $15000 \mathrm{~g}$ for $5 \mathrm{~min}$. The DNA-containing supernatant was placed in a new Eppendorf tube and stored at $4{ }^{\circ} \mathrm{C}$. More than $95 \%$ of the total 16S rRNA gene sequences of strains LJ96 (1474 bp), LJ79 (1471 bp) and LJ99 (1420 bp) were determined. PCR amplification $\left(25\right.$ cycles at $94^{\circ} \mathrm{C}$ for $30 \mathrm{~s}, 61^{\circ} \mathrm{C}$ for $30 \mathrm{~s}$ and $72{ }^{\circ} \mathrm{C}$ for $2 \mathrm{~min}$ followed by $1 \mathrm{cycle}$ at $72^{\circ} \mathrm{C}$ for $6 \mathrm{~min}$ ) of the $16 \mathrm{~S}$ rRNA gene sequences was done in PCR tubes containing $1 \mu \mathrm{l}$ of the DNA extract and $0.5 \mu \mathrm{M}$ of each primer SDBact0008aS20 [5'-AGAGTTTGATC(AC)TGGCTCAG-3'] and $S^{\star}$ UNIV518Aa18 (5'-GTATTACCGCGGCTGCTG- $3^{\prime}$ ), $250 \mu \mathrm{M}$ of each dNTP, $1 \times$ PCR buffer, $0.5 \mathrm{mM} \mathrm{MgCl}_{2}$ and $0.5 \mathrm{U}$ Taq DNA polymerase. PCR products were purified using the QIAquick PCR purification kit (Qiagen) following the manufacturer's instructions. MWG-BIOTECH (http:// www.mwg-biotech.com) sequenced the PCR products on a NEN Global IR ${ }^{2}$ DNA Sequencer Li-COR using the primer SDBact008aS20. Sequences were compared to sequences in nucleotide databases using the BLASTN 2.2.6 search program (http://www.ncbi.nlm.nih.gov) (Altschul et al., 1997). Representatives of relatives were used to construct a phylogenetic tree where Escherichia coli K-12 (E05133) was used as an outgroup. Sequences were aligned using the algorithm CLUSTAL W (Thompson et al., 1994) in the program BIOEDIT (Hall, 1999). All sequences were trimmed at the left and right ends and a total of 1338 bp were used for construction of the phylogenetic tree. Tree calculations were done in TREECON (version 1.3b) (Van de Peer \& De Wachter, 1994) using the Jukes \& Cantor (1969) substitution model followed by the neighbour-joining algorithm of Saitou \& Nei (1987). Bootstrap values were collected for 1000 
phylogenetic trees (Felsenstein, 1985). Genomic characterization by ERIC (enterobacterial repetitive intergenic consensus sequence) PCR on $1 \mu \mathrm{l}$ DNA extracts was performed in a HYBAID pcrEXPRESS HBPX-220 thermocycler using a modified procedure of De Bruijn (1992). The primers used were R1CIRE (5'-CACTTAGGGGTCCTCGAATGTA- $3^{\prime}$ ) and ERIC2 (5'-AAGTAAGTGACTGGGGTGAGCG-3'). The program used was as follows: 1 cycle at $95^{\circ} \mathrm{C}$ for $20 \mathrm{~s}$ followed by 35 cycles of $94^{\circ} \mathrm{C}$ for $5 \mathrm{~s}, 54^{\circ} \mathrm{C}$ for $1 \mathrm{~min}$ and $72{ }^{\circ} \mathrm{C}$ for $2 \mathrm{~min}, 1 \mathrm{cycle}$ at $72^{\circ} \mathrm{C}$ for $16 \mathrm{~min}$ and a final soak at $4{ }^{\circ} \mathrm{C}$. Random amplified polymorphic DNA (RAPD) PCR was performed with three 10-base primers [OPA04 (5'AATCGGGCTG-3'), OPA07 (5'-GAAACGGGTG-3') and OPA15 (5'-TTCCGAACCC-3'); Operon Technologies Inc.] according to Hansen \& Winding (1998). DNA base composition $(\mathrm{G}+\mathrm{C}$ content) was determined by the DSMZ by HPLC as described previously (Mesbah et al., 1989; Tamaoka \& Komagata, 1984; Visuvanathan et al., 1989). DNA-DNA hybridization experiments were performed by the DSMZ using strains LJ79, LJ96 ${ }^{\mathrm{T}}$, LJ99, Frateuria aurantia DSM $6220^{\mathrm{T}}$ and Fulvimonas soli DSM $14263^{\mathrm{T}}$. DNA was isolated using a French pressure cell (Thermo Spectronic) and purified by chromatography on hydroxyapatite as described by Cashion et al. (1977). The hybridization reactions were performed at $68^{\circ} \mathrm{C}$ in $2 \times$ SSC plus $10 \%(\mathrm{v} / \mathrm{v})$ DMSO $(1 \times \mathrm{SSC}$ is $0 \cdot 15 \mathrm{M} \mathrm{NaCl}$ plus $15 \mathrm{mM}$ sodium citrate) as described by De Ley et al. (1970), with the modifications of Huß et al. (1983) and Escara \& Hutton (1980), on a model 2600 spectrophotometer equipped with a model 2527-R thermoprogrammer and plotter (Gilford Instrument Laboratories). Renaturation rates were computed with the TRANSFER.BAS program of Jahnke (1992).

Strains LJ79, $\mathrm{LJ96}^{\mathrm{T}}$ and LJ99 were Gram-negative, motile rods $(1.0 \times 0.4 \mu \mathrm{m})$ with one polar flagellum $10-15 \mu \mathrm{m}$ long (Fig. 1) and formed yellow colonies on 1/10 TSBA. They were catalase- and oxidase-positive and grew on 1/10 TSBA, full-strength TSBA and MacConkey agar. The colony colour changed from yellow to weak orange by addition of $10 \% \mathrm{KOH}$. The colour change is a phenolate reaction that can be observed with several bacterial pigment types

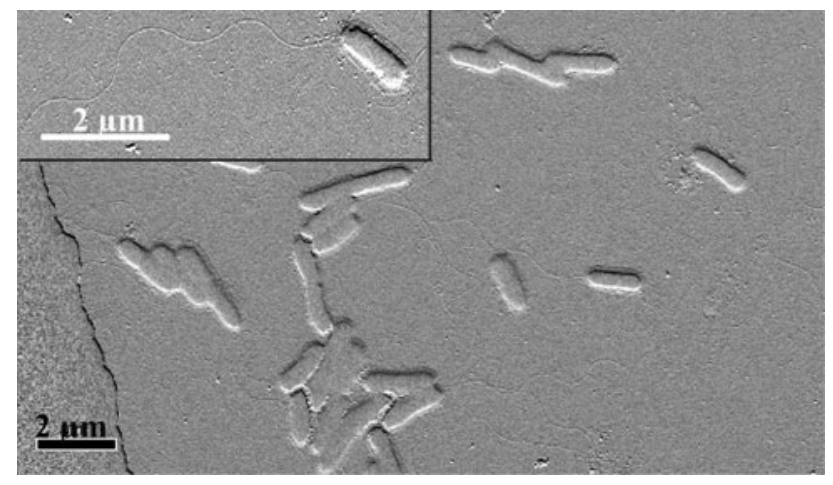

Fig. 1. Scanning electron micrographs showing cells of LJ96 ${ }^{\top}$. Bars, $2 \mu \mathrm{m}$.
(Reichenbach, 1992). Growth was observed on 1/10 TSBA between 5 and $30^{\circ} \mathrm{C}$ but not at $37^{\circ} \mathrm{C}$, at $\mathrm{pH}$ 6-9 and at $0-3 \% \mathrm{NaCl}$ but not at $5 \%$. Other biochemical and physiological characteristics of the strains are presented in Table 1. The fatty acid composition of LJ96 ${ }^{\mathrm{T}}$ consisted mainly of branched $15: 0$ iso $(23 \cdot 4 \%), 17: 1$ iso $\omega 9 c(25 \cdot 5 \%)$ and $17: 0$ iso $(18 \cdot 1 \%)$ (detailed results are available in Supplementary Table S1 in IJSEM Online). Of the main branched fatty acids, $17: 1$ iso $\omega 9 c$ and $17: 0$ iso were found in larger proportions and $15: 0$ in a smaller proportion in $2 J 96^{\mathrm{T}}$ than in Fulvimonas soli DSM $14263^{\mathrm{T}}$. Four fatty acids $(15: 0$ iso, $15: 0$ anteiso, $16: 0$ and $16: 1 \omega 9 c)$ comprise $35-60 \%$ of the total fatty acid profiles of xanthomonads (Norman et al., 1997) and quantitative variation of these fatty acids has been used to differentiate among species of Xanthomonas (Chase et al., 1992). LJ96 ${ }^{\mathrm{T}}$ had a fatty acid value of $30 \%$ of the total profile (15:0 iso, 15:0 anteiso and 16:0) and this low value may be used as a differentiating character from other members of the family Xanthomonadaceae.

Analysis of the phylogenetic position of the strains demonstrated that they belonged to the family Xanthomonadaceae within the Xanthomonadales of the Gammaproteobacteria (Fig. 2). The highest similarity values were found for the genera Rhodanobacter (96\%), Frateuria (95\%) and Fulvimonas (96\%) (Fig. 2). Other members of the Xanthomonadales were distantly related (83-91\% similarity). DNA-DNA hybridization was performed with $\mathrm{LJ} 96^{\mathrm{T}}$ as a probe against LJ79, LJ99, Frateuria aurantia DSM $6220^{\mathrm{T}}$ and Fulvimonas soli DSM $14263^{\mathrm{T}}$ (Rhodanobacter lindaniclasticus LMG $18385^{\mathrm{T}}$ was not available, as described above) to evaluate the closeness of their relationship. The results of the DNA-DNA hybridizations showed that LJ79, LJ96 ${ }^{\mathrm{T}}$ and LJ99 could be considered as one species $(87 \cdot 4$ to $98.7 \%$ relatedness to the probe) while Frateuria aurantia DSM $6220^{\mathrm{T}}$ and Fulvimonas soli DSM $14263^{\mathrm{T}}$ comprised two other species (i.e. below $31 \%$ relatedness to the probe) (Stackebrandt \& Goebel, 1994). The DNA G +C content of strains $\mathrm{LJ} 96^{\mathrm{T}}$ was $64 \cdot 3 \mathrm{~mol} \%$, which is very close to the values reported for Frateuria aurantia DSM $6220^{\mathrm{T}}$ $(63.5 \mathrm{~mol} \%)$ and Rhodanobacter lindaniclasticus LMG $18385^{\mathrm{T}}(63.0 \mathrm{~mol} \%)$ but considerably lower than the $71.7 \mathrm{~mol} \%$ of Fulvimonas soli DSM $14263^{\mathrm{T}}$ (Table 1). ERIC-PCR banding patterns of the three strains were identical but different from Frateuria aurantia DSM $6220^{\mathrm{T}}$ and Fulvimonas soli DSM $14263^{\mathrm{T}}$ (see Supplementary Fig. S1a in IJSEM Online). RAPD banding patterns, on the other hand, revealed differences between the three strains, and between the strains and Frateuria aurantia DSM $6220^{\mathrm{T}}$ and Fulvimonas soli DSM $14263^{\mathrm{T}}$ (Supplementary Fig. S1b), indicating a non-clonal origin of LJ79, $\mathrm{LJ}^{\mathrm{T}} \mathrm{6}^{\mathrm{T}}$ and LJ99, a result also found by DNA-DNA hybridization (Table 1).

Three of the six closest relatives of LJ79, LJ96 ${ }^{\mathrm{T}}$ and LJ99 (Fig. 2) based on 16S rRNA gene sequence analysis were obtained by cloning of rRNA from different habitats. The sequences AJ318146 and AY081991 originated from soil 
Table 1. Biochemical and physiological characteristics that differentiate strains LJ79, LJ96 ${ }^{\top}$ and LJ99 from their closest cultured relatives

Species/strains: 1, Luteibacter rhizovicinus gen. nov., sp. nov.; 2, Rhodanobacter lindaniclasticus LMG $18385^{\mathrm{T}}$ (data from Nalin et al., 1999); 3, Frateuria aurantia DSM 6220 ${ }^{\mathrm{T}}$ (Swings et al., 1980; this study); 4, Fulvimonas soli DSM $14263^{\mathrm{T}}$ (Mergaert et al., 2002; this study); 5, Xanthomonas campestris LMG $568^{\mathrm{T}}$ (Van den Mooter \& Swings, 1990; Vauterin et al., 1995). The genera Rhodanobacter, Frateuria and Fulvimonas consist of single species only. Characteristics are scored as: +, positive; - , negative; \pm , weak; d, strain-dependent; ND, not determined. All L. rhizovicinus strains were positive for the following tests: catalase; utilization of $\mathrm{N}$-acetylglucosamine, D-glucose, D-fructose, D-mannose, Dfucose, galactose, cellobiose, lactose, melibiose, sucrose and trehalose, growth at 5, 10, 15, 20 and $30^{\circ} \mathrm{C}$, $\mathrm{pH} 6,7,8$ and 9 and in media containing $0,0 \cdot 5,1,2$ and $3 \% \mathrm{NaCl}$ and change of colony colour (yellow to weak orange). All L. rhizovicinus strains were negative for the following tests: activity of the hydrolytic enzymes $\alpha$-amylase, $\alpha$-cellulase, $\beta$-xylanase and arginine dihydrolase, utilization of arginine, urea, maltose, mannitol, gluconate, caprate, adipate, malate, phenylacetate, glycerol, erythritol, D-arabinose, Larabinose, ribose, D-xylose, L-xylose, adonitol, methyl $\beta$-xyloside, L-sorbose, rhamnose, dulcitol, inositol, mannitol, sorbitol, methyl $\alpha$-D-mannoside, methyl $\alpha$-D-glucoside, amygdalin, arbutin, salicin, inulin, melezitose, D-raffinose, starch, glycogen, xylitol, D-turanose, D-tagatose, L-fucose, D-arabitol, L-arabitol, gluconate, 2-ketogluconate and 5-ketogluconate, nitrate reduction, indole production, growth at $37^{\circ} \mathrm{C}$ and in $5 \% \mathrm{NaCl}$.

\begin{tabular}{|c|c|c|c|c|c|c|}
\hline \multirow[t]{2}{*}{ Characteristic } & \multicolumn{2}{|c|}{1} & \multirow[t]{2}{*}{2} & \multirow[t]{2}{*}{3} & \multirow[t]{2}{*}{4} & \multirow[t]{2}{*}{5} \\
\hline & LJ79, LJ99 & LJ96 ${ }^{\mathrm{T}}$ & & & & \\
\hline Motility & + & + & - & + & + & + \\
\hline Acid from D-glucose & - & - & - & + & + & + \\
\hline \multicolumn{7}{|l|}{ Growth on: } \\
\hline$\beta$-Gentiobiose & $-1+$ & + & - & - & - & + \\
\hline D-Lyxose & $-1+$ & + & - & - & - & ND \\
\hline Maltose & - & - & - & + & + & + \\
\hline Citrate & - & - & + & - & - & ND \\
\hline MacConkey agar & + & + & $\mathrm{ND}$ & - & - & ND \\
\hline \multicolumn{7}{|l|}{ Enzyme activities: } \\
\hline Oxidase & + & + & + & - & + & \pm \\
\hline Protease (skimmed milk) & + & + & - & - & + & + \\
\hline$\beta$-Galactosidase & + & + & - & - & + & $\mathrm{ND}$ \\
\hline \multicolumn{7}{|l|}{ Hydrolysis of: } \\
\hline Aesculin & + & + & + & - & + & + \\
\hline Starch & + & + & $\mathrm{ND}$ & \pm & + & $\mathrm{d}^{*}$ \\
\hline Gelatin & + & + & $\mathrm{ND}$ & - & - & + \\
\hline \multicolumn{7}{|l|}{ Growth at: } \\
\hline $5^{\circ} \mathrm{C}$ & + & + & - & - & - & - \\
\hline $10{ }^{\circ} \mathrm{C}$ & + & + & $\mathrm{ND}$ & - & - & ND \\
\hline $37^{\circ} \mathrm{C}$ & - & - & + & + & - & - \\
\hline $41^{\circ} \mathrm{C}$ & - & - & + & - & - & - \\
\hline Anaerobic growth on $1 / 10$ TSBA & + & + & $\mathrm{ND}$ & + & + & - \\
\hline $\begin{array}{l}\text { DNA-DNA hybridization (\%) } \\
\text { with } \mathrm{LJ}^{\mathrm{T}} 6^{\mathrm{T}} \text { as a probe } \dagger\end{array}$ & $98 \cdot 3 / 87 \cdot 4$ & $98 \cdot 7$ & $\mathrm{ND}$ & $29 \cdot 7$ & $30 \cdot 3$ & $\mathrm{ND}$ \\
\hline Mean DNA G + C $(\mathrm{mol} \%)$ & ND & $64 \cdot 3$ & $63 \cdot 0$ & $71 \cdot 7$ & $63 \cdot 5$ & $65 \cdot 8-66 \cdot 6$ \\
\hline
\end{tabular}

${ }^{*} 75 \%$ of 189 X. campestris strains tested positive (Van den Mooter \& Swings, 1990).

$\dagger$ Determined at $68^{\circ} \mathrm{C}$ in $2 \times$ SSC plus $10 \%(\mathrm{v} / \mathrm{v})$ DMSO.

habitats contaminated with xenobiotics, whereas sequence AY218686 came from penguin dropping sediments from Ardley Island, Antarctica. The sequence AY162032 had $98 \cdot 5 \%$ similarity to the sequences of LJ79, LJ96 ${ }^{\mathrm{T}}$ and LJ99, and originated from a tropical forest soil isolate sampled in Ghana. Sequence AY162032 was obtained by cultivation of samples in gel microdroplets (Zengler et al., 2002). The three strains Rhodanobacter lindaniclasticus LMG $18385^{\mathrm{T}}$, Frateuria aurantia DSM $6220^{\mathrm{T}}$ and Fulvimonas soli DSM $14263^{\mathrm{T}}$ all originated from soil environments (as previously 


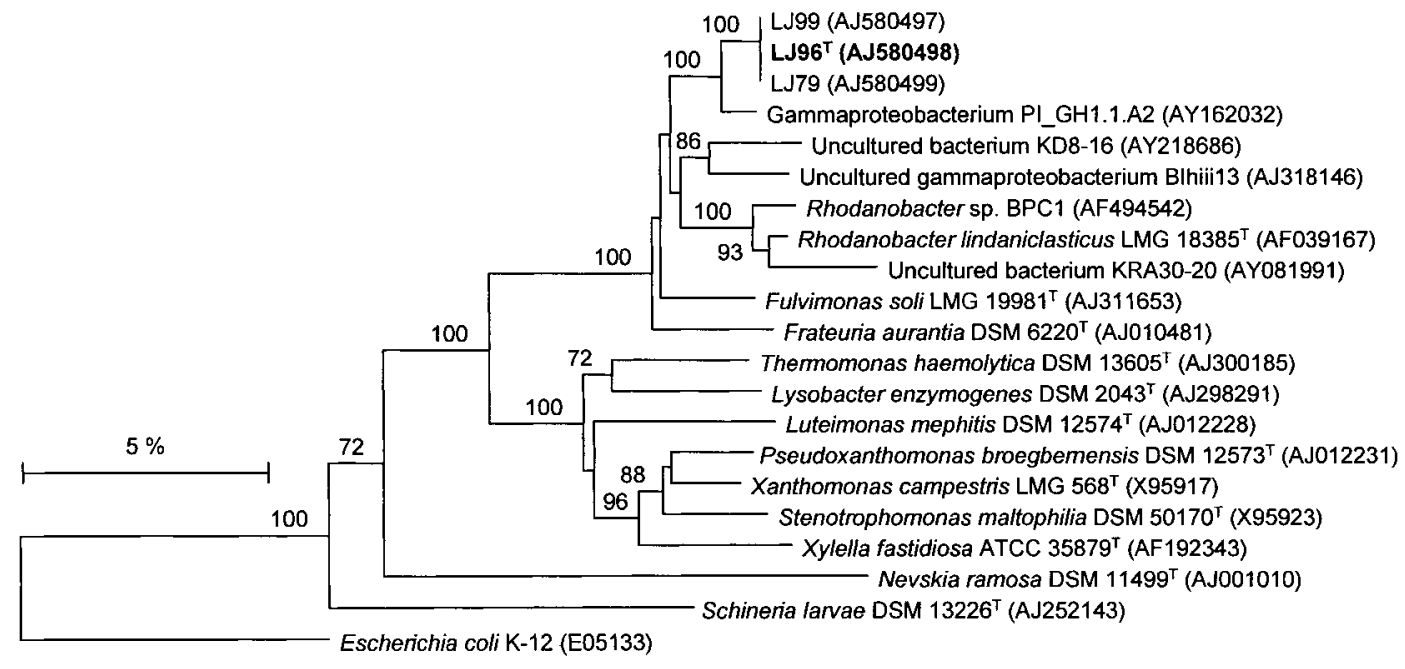

Fig. 2. Neighbour-joining tree of $16 \mathrm{~S}$ rRNA gene sequence similarity, showing the phylogenetic position of strains LJ79, LJ96 ${ }^{\top}$, LJ99 and representatives of closely related isolates and other more distantly related genera of the family Xanthomonadaceae. Bootstrap percentages are indicated at branches and calculated from 1000 trees. Escherichia coli K-12 (E05133) was used as an outgroup. Sequence accession numbers are shown in parentheses.

described). Our stains were isolated from an agricultural field located in Denmark after growth on a standard soil bacterial substrate. Altogether, this suggests that members of the Xanthomonadaceae are adapted to soil habitats around the world and can be retrieved by a wide spectrum of cultivation and purification techniques.

In conclusion, we propose a novel genus within the Xanthomonadaceae with the name Luteibacter gen. nov., containing the species Luteibacter rhizovicinus gen. nov., sp. nov. (Fig. 2). This new genus can be separated from its nearest relatives by phenotypic characteristics (Table 1 ). Luteibacter rhizovicinus can be differentiated $(96 \% 16 \mathrm{~S}$ rRNA gene sequence similarity) from Rhodanobacter lindaniclasticus (of which the type strain is currently not available) by its mobility, protease activity and growth below $10{ }^{\circ} \mathrm{C}$, and from Frateuria aurantia by being oxidasepositive, capable of growing on MacConkey agar, protease activity, hydrolysis of aesculin and gelatin, growth below $10{ }^{\circ} \mathrm{C}$ and $\mathrm{G}+\mathrm{C}$ content. Further, Fulvimonas soli differs from our three strains by the absence of hydrolysis of gelatin and its failure to grow below $10{ }^{\circ} \mathrm{C}$.

\section{Description of Luteibacter gen. nov.}

Luteibacter (Lu.te.i.bac'ter. L. adj. luteus yellow; N.L. masc. n. bacter rod; N.L. masc. n. Luteibacter yellow rod).

Cells are Gram-negative, single rod and motile by a polar flagellum; no spores or capsules are observed. Aerobic, chemo-organotroph, mesophilic (between $5-30{ }^{\circ} \mathrm{C}$ but not at $\left.37^{\circ} \mathrm{C}\right), \mathrm{pH}$ range $6-9$ and tolerant to $0-3 \%(\mathrm{w} / \mathrm{v}) \mathrm{NaCl}$. Aesculin, starch and gelatin are hydrolysed. Colony colour is yellow after growth on 1/10-strength and full-strength TSBA. Colony colour change from yellow to weak orange by addition of $10 \% \mathrm{KOH}$. Catalase- and oxidase-positive. Fatty acids are mainly branched $(15: 0$ iso, $17: 1$ iso $\omega 9 c, 17: 0$ iso). The genus Luteibacter belongs to the family Xanthomonadaceae in the class Gammaproteobacteria. The type species is Luteibacter rhizovicinus.

\section{Description of Luteibacter rhizovicinus sp. nov.}

Luteibacter rhizovicinus (rhi.zo.vi.ci'nus. Gr. n. rhiza root; L. masc. adj. vicinus neighbouring; N.L. masc. adj. rhizovicinus neighbouring a root, referring to the rhizosphere, soil closely related to plant roots, from where the type strain was isolated).

Displays the following properties in addition to those given in the genus description. Yellow, low-convex colonies, 3-5 $\mathrm{mm}$ in diameter and with an entire edge after $48 \mathrm{~h}$ at $20^{\circ} \mathrm{C}$ when grown on $1 / 10$ TSBA. Characteristics of the species are presented in Table 1 . The fatty acid composition consists mainly of branched $15: 0$ iso $(23 \cdot 4 \%), 17: 1$ iso $\omega 9 c$ $(25 \cdot 5 \%)$ and $17: 0$ iso $(18 \cdot 1 \%)$ (detailed results are available in Supplementary Table S1). The DNA G+C content of the type strain is $64 \cdot 3 \mathrm{~mol} \%$.

The type strain is $\mathrm{LJ}^{\mathrm{T}}{ }^{\mathrm{T}}\left(=\mathrm{DSM} 16549^{\mathrm{T}}=\mathrm{ATCC}\right.$ BAA$1015^{\mathrm{T}}$ ), isolated from the rhizosphere of a spring barley plant (Hordeum vulgare L.) at Højbakkegaard (Taastrup, Denmark).

\section{Acknowledgements}

The authors acknowledge the skilled technical assistance by Heidi Irming, Margit Møller Fernqvist and Christina J. Lenhard. Professor Dr Hans G. Trüper is thanked for help with the Latin names. J.E. J. was supported by the Center for Bioethics and Risk Assessment under the Danish Research Council. 


\section{References}

Altschul, S. F., Madden, T. L., Schäffer, A. A., Zhang, J., Zhang, Z., Miller, W. \& Lipman, D. J. (1997). Gapped BLAST and PSI-BLAST: a new generation of protein database search programs. Nucleic Acids Res 25, 3389-3402.

Buck, J. D. (1982). Nonstaining (KOH) method for determination of Gram reactions of marine bacteria. Appl Environ Microbiol 44, 992-993.

Cashion, P., Holder-Franklin, M. A., McCully, J. \& Franklin, M. (1977). A rapid method for the base ratio determination of bacterial DNA. Anal Biochem 81, 461-466.

Chase, A. R., Stall, R. E., Hodge, N. C. \& Jones, J. B. (1992). Characterization of Xanthomonas campestris strains from aroids using physiological, pathological, and fatty acid analysis. Phytopathology 82, 754-759.

De Bruijn, F. J. (1992). Use of repetitive (repetitive extragenic palindromic and enterobacterial repetitive intergeneric consensus) sequences and the polymerase chain reaction to fingerprint the genomes of Rhizobium meliloti isolates and other soil bacteria. Appl Environ Microbiol 58, 2180-2187.

De Ley, J., Cattoir, H. \& Reynaerts, A. (1970). The quantitative measurement of DNA hybridization from renaturation rates. Eur $J$ Biochem 12, 133-142.

Drancourt, M., Bollet, C. \& Raoult, D. (1997). Stenotrophomonas africana sp. nov., an opportunistic human pathogen in Africa. Int J Syst Bacteriol 47, 160-163.

Escara, J. F. \& Hutton, J. R. (1980). Thermal stability and renaturation of DNA in dimethyl sulfoxide solutions: acceleration of the renaturation rate. Biopolymers 19, 1315-1327.

Felsenstein, J. (1985). Confidence limits on phylogenies: an approach using the bootstrap. Evolution 39, 783-791.

Finkmann, W., Altendorf, K., Stackebrandt, E. \& Lipski, A. (2000). Characterization of $\mathrm{N}_{2} \mathrm{O}$-producing Xanthomonas-like isolates from biofilters as Stenotrophomonas nitritireducens sp. nov., Luteimonas mephitis gen. nov., sp. nov. and Pseudoxanthomonas broegbernensis gen. nov., sp. nov. Int J Syst Evol Microbiol 50, 273-282.

Germida, J. J., Siciliano, S. D., de Freitas, J. R. \& Seib, A. M. (1998). Diversity of root-associated bacteria associated with held-grown canola (Brassica napus L.) and wheat (Triticum aestivum L.). FEMS Microbiol Ecol 26, 43-50.

Hall, T. A. (1999). BioEdit: a user-friendly biological sequence alignment editor and analysis program for Windows 95/98/NT. Nucleic Acids Symp Ser 41, 95-98.

Hansen, B. M. \& Winding, A. (1998). Detection of Pseudomonas putida B in the rhizosphere by RAPD. Lett Appl Microbiol 24, 249-225.

Hauben, L., Vauterin, L., Moore, E. R. B., Hoste, B. \& Swings, J. (1999). Genomic diversity of the genus Stenotrophomonas. Int J Syst Bacteriol 49, 1749-1760.

Huß, V. A. R., Festl, H. \& Schleifer, K. H. (1983). Studies on the spectrophotometric determination of DNA hybridization from renaturation rates. Syst Appl Microbiol 4, 184-192.

Jahnke, K. D. (1992). Basic computer program for evaluation of spectroscopic DNA renaturation data from GILFORD System 2600 spectrometer on a PC/XT/AT type personal computer. J Microbiol Methods 15, 61-73.

Johansen, J. E. \& Binnerup, S. J. (2002). Contribution of Cytophagalike bacteria to the potential of turnover of carbon, nitrogen, and phosphorus by bacteria in the rhizosphere of barley (Hordeum vulgare L.). Microb Ecol 43, 298-306.
Jukes, T. H. \& Cantor, C. R. (1969). Evolution of protein molecules. In Mammalian Protein Metabolism, pp. 21-132. Edited by H. N. Munro. New York: Academic Press.

Lilley, A. K., Fry, J. C., Bailey, M. J. \& Day, M. J. (1996). Comparison of aerobic heterotrophic taxa isolated from four root domains of mature sugar beet (Beta vulgaris). FEMS Microbiol Ecol 21, 231-242.

Mahaffee, W. F. \& Kloepper, J. W. (1997). Temporal changes in the bacterial communities of soil, rhizosphere, and endorhiza associated with field-grown cucumber (Cucumis sativus L.). Microb Ecol 34, 210-223.

Marilley, L. \& Aragno, M. (1999). Phylogenetic diversity of bacterial communities differing in degree of proximity of Lolium perenne and Trifolium repens roots. Appl Soil Ecol 13, 127-136.

Mergaert, J., Cnockaert, M. C. \& Swings, J. (2002). Fulvimonas soli gen. nov., sp. nov., a $\gamma$-proteobacterium isolated from soil after enrichment on acetylated starch plastic. Int J Syst Evol Microbiol 52, 1285-1289.

Mesbah, M., Premachandran, U. \& Whitman, W. B. (1989). Precise measurement of the $\mathrm{G}+\mathrm{C}$ content of deoxyribonucleic acid by high-performance liquid chromatography. Int J Syst Bacteriol 39, 159-167.

Nalin, R., Simonet, P., Vogel, T. M. \& Normand, P. (1999). Rhodanobacter lindaniclasticus gen. nov., sp. nov., a lindane-degrading bacterium. Int J Syst Bacteriol 49, 19-23.

Norman, D. J., Chase, A. R., Hodge, H. C. \& Stall, R. E. (1997). Differentiation of three species of Xanthomonas and Stenotrophomonas maltophilia using cellular fatty acid analysis. Eur J Plant Pathol 103, 687-693.

Reichenbach, H. (1992). The order Cytophagales. In The Prokaryotes. A Handbook of Biology of Bacteria: Ecophysiology, Isolation, Identification, Applications, 2nd edn, pp. 3631-3675. Edited by A. Balows, H. G. Trüper, H. Dworkin, W. Harder \& K. H. Schleifer. Heidelberg: Springer.

Saitou, N. \& Nei, M. (1987). The neighbor-joining method: a new method for reconstructing phylogenetic trees. Mol Biol Evol 4, 406-425.

Sasser, M. (1990). Identification of bacteria by gas chromatography of cellular fatty acids. USFCC Newsl 20, 1-6.

Stackebrandt, E. \& Goebel, B. M. (1994). Taxonomic note: a place for DNA-DNA reassociation and 16S rRNA sequence analysis in the present species definition in bacteriology. Int J Syst Bacteriol 44, 846-849.

Swings, J., Gillis, M., Kersters, K., De Vos, P., Gosselé, F. \& De Ley, J. (1980). Frateuria, a new genus for Acetobacter aurantius. Int J Syst Bacteriol 30, 547-556.

Tamaoka, J. \& Komagata, K. (1984). Determination of DNA base composition by reversed-phase high-performance liquid chromatography. FEMS Microbiol Lett 25, 125-128.

Thompson, J. D., Higgins, D. G. \& Gibson, T. J. (1994). CLUSTAL W: improving the sensitivity of progressive multiple sequence alignment through sequence weighting, position-specific gap penalties and weight matrix choice. Nucleic Acids Res 22, 4673-4680.

Van den Mooter, M. \& Swings, J. (1990). Numerical analysis of 295 phenotypic features of 266 Xanthomonas strains and related strains and an improved taxonomy of the genus. Int J Syst Bacteriol 40, 348-369.

Van de Peer, Y. \& De Wachter, R. (1994). TREECON for Windows: a software package for the construction and drawing of evolutionary trees for the Microsoft Windows environment. Comput Appl Biosci 10, 569-570.

Vauterin, L., Hoste, B., Kersters, K. \& Swings, J. (1995). Reclassification of Xanthomonas. Int J Syst Bacteriol 45, 472-489. 
Visuvanathan, S., Moss, M. T., Standord, J. L., Hermon-Taylor, J. \& McFadden, J. J. (1989). Simple enzymatic method for isolation of DNA from diverse bacteria. J Microbiol Methods 10, 59-64.

Wells, J. M., Raju, B. C., Hung, H.-Y., Weisburg, W. G., MandelcoPaul, L. \& Brenner, D. J. (1987). Xylella fastidiosa gen. nov., sp. nov.: gram-negative, xylem-limited, fastidious plant bacteria related to Xanthomonas spp. Int J Syst Bacteriol 37, 136-143.

Zengler, K., Toledo, G., Rappe, M., Elkins, J., Mathur, E. J., Short, J. M. \& Keller, M. (2002). Cultivating the uncultured. Proc Natl Acad Sci U S A 99, 15681-15686. 